\author{
Thi-Qar Medical Journal (TQMJ): Vol.(12), No.(2), 2016 \\ Email:utjmed@utq.edu.iq \\ Web Site: https://imed.utq.edu.iq
}

\title{
Effect of Nosocomial Burn Bacteria in Experimental
}

\section{Burn Model}

\author{
Haydar Kh. Al-Maliky ${ }^{*} \&$ Rahman Laibi Chelab ${ }^{* *}$ \\ *College of Medicine / Thi-Qar University \\ **College of Education for Pure Science / Thi-Qar University. \\ *haydar.shanan@utq.edu.iq
}

\begin{abstract}
:
In present study, mice burn model were used to study the complications of bacterial infected burn cases. Eighteen male albino mice were used as a burn model which divided into two mice groups burned by boiled water (scald method), then injected by physiological normal saline (negative control), two mice were infected by Pseudomonas aeruginosa $0.2 \times 10^{8}$ Colony Form Unit (CFU) without burn, on other hand two mice were infected by Staphylococcus aureus $\left(0.2 \times 10^{8} \mathrm{CFU}\right)$ without burn, these two groups considered as a positive control. Other mice divided into two groups, each one contains six mice burned and infected by nosocomial bacterial burn isolates $\left(0.2 \times 10^{8} \mathrm{CFU}\right)$, all groups were followed up for 7 days then killed and histopathological changes of some internal organs were examined, livers and lungs of examined samples showed significant pathological changes in coparision to the negative control, suggesting that these samples suffered from variety degree of hepatitis and pneumonia. These results were due to the complications of bacteremia and septicemia of burned model.
\end{abstract}

\section{Introduction:}

The mortality rate in burns during the last decades is declining due to the development of clinical treatment of this severe trauma(1). However, in the USA there are still more than a million cases of burns per year (2), resulting in more than half a million cases being treated in emergency room (3). According to the World Health Organization (WHO), around 300.000 deaths are estimated per year world wide due to burns (4). Burns are responsible for many

pathophysiological changes $(5,6)$, representing a severe form of trauma which may result in complications such as: a rise in infection rate, an increase in hospital stay, prolonged time of inactivity and also a greater mortality rate $(7,8)$. Among other changes, concerning reintegration into society post discharge, psychological 


\section{Email:utjmed@utq.edu.iq}

changes are also observed such as post-traumatic stress syndrome in the cases of victims of extensive burns $(5,9,10)$. Although presently more patients with burns die of pneumonia than of burn wound infection, burn wound sepsis remains an important infectious complication in this population. Thermal injury to the skin causes a massive release of humoral factors, including cytokines, prostaglandins, vasoactive prostanoids, and leukotrienes (11). Accumulation of these factors at the site of injury results in "spillover" into the systemic circulation, giving rise to immunosuppression. All arms of the immune system are involved in this immunosuppression. Chemotaxis of neutrophils is decreased, as are phagocytic and bactericidal activity(12). Some laboratory animals such as rat, mice, hamster and rabbits have been used as study - models for understanding the stages of healing due to sharing many physiological and pathological characteristics of human systems (13). I addition, rodents are small size, cheap and easy to maintain in the lab. Such studies have advantages of presenting physiological and pathological effects similar to those of human, considering stimulating the nervous, cardiovascular, endocrine and immunological system (14). The current study aimed mainly to study the potential histopathological effects of nosocomial burn isolates in experimental mice burn model.

\section{Material and methods:}

Web Site: https://imed.utq.edu.iq

Bacterial isolates: Bacterial burn isolates were obtained from Missan Teaching hospital (burn unit). $P$. aeruginosa and $S$. aureus were identified according to standard methods by Vitek system.

Infectious dose: Bacterial dose was 10 8 colony form unit (CFU) for each bacterial isolates. In addition, route of infection was scratched and subcutaneous in burn area (16).

An experimental burn mice model: Four mice groups were used in this study as described below:

1.Negative control: three male mice were burned (third degree) by hot water (boiling), then injected with 0.2 $\mathrm{ml}$ normal saline.

2.Positive control: three groups, each group contains three male mice were infected with $P$. aeruginosa without burn process. On the other hand, three male mice also were infected with $S$. aureus without burn.

3.Six male mice were burned and infected with $P$. aeruginosa and follow up for seven days.

4.Six male mice were burned, infected with $S$. aureus and followed for seven days.

\section{Histopathological study:}

All experimental mice model were killed at the end of the experiments, their lungs and livers were isolated by aseptic methods, and sampled for histopathological examination. Tissues processing was carried out using routine procedures (Mohan, 2007). 


\section{Results:}

Aseptic methods were used to isolate the lungs and livers of the experimental mice burn model and used for histopathological changes are widely used to study the effects of bacterial burn infection.

1-Negative control group: No significant pathological changes were observed in this group as explained in Fig. 1a, b.

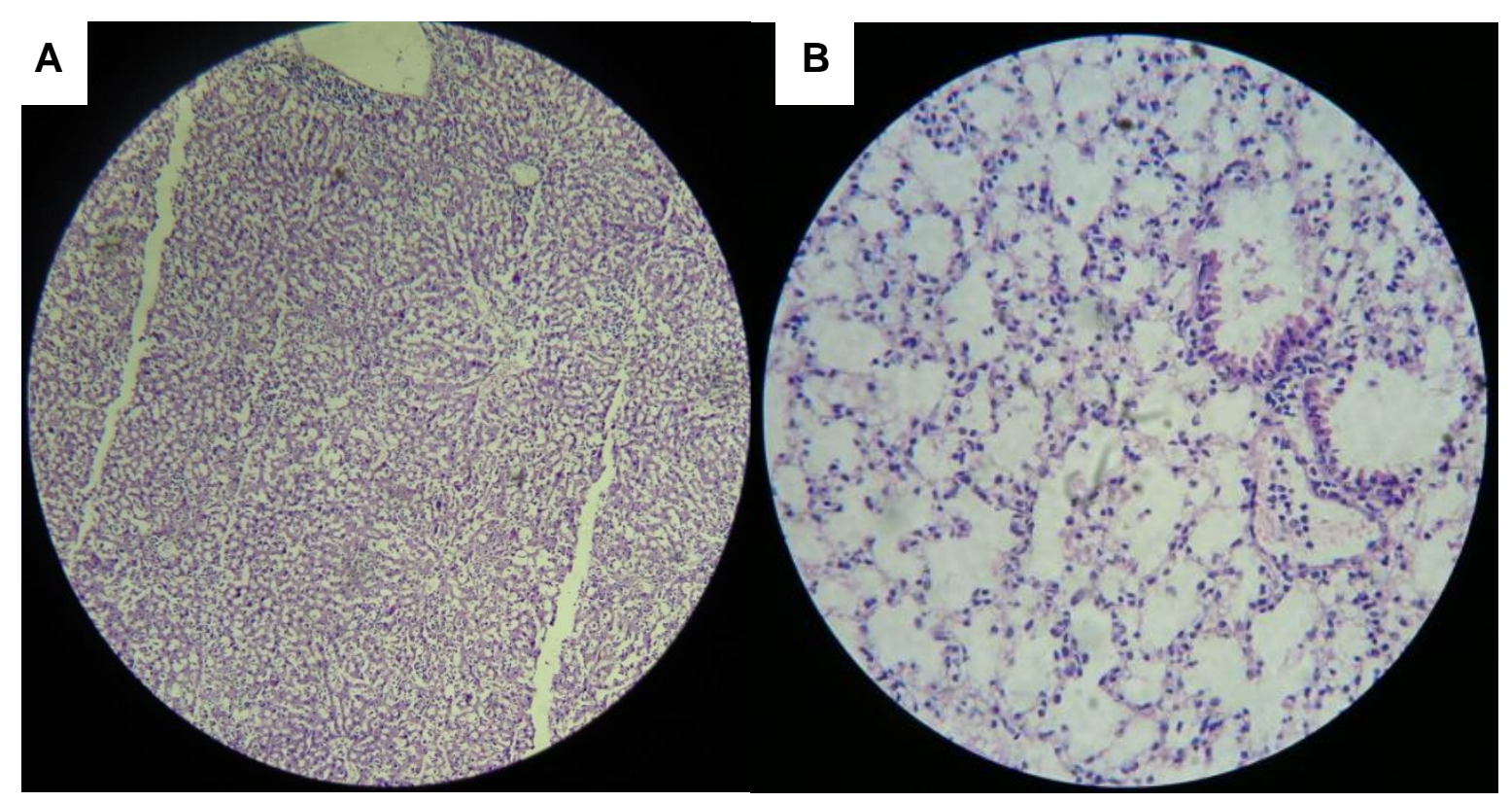

Fig1: Photomicrograph of the liver (a) H\&E, 10X and lung (b) H\&E 40X of negative control group showing no significant pathological changes.

2-Positive control: An acute hepatitis was observed in liver sections of positive control group (Fig 20. Nevertheless, sections of the examined lungs were normal and no significant pathological changes were detected. 


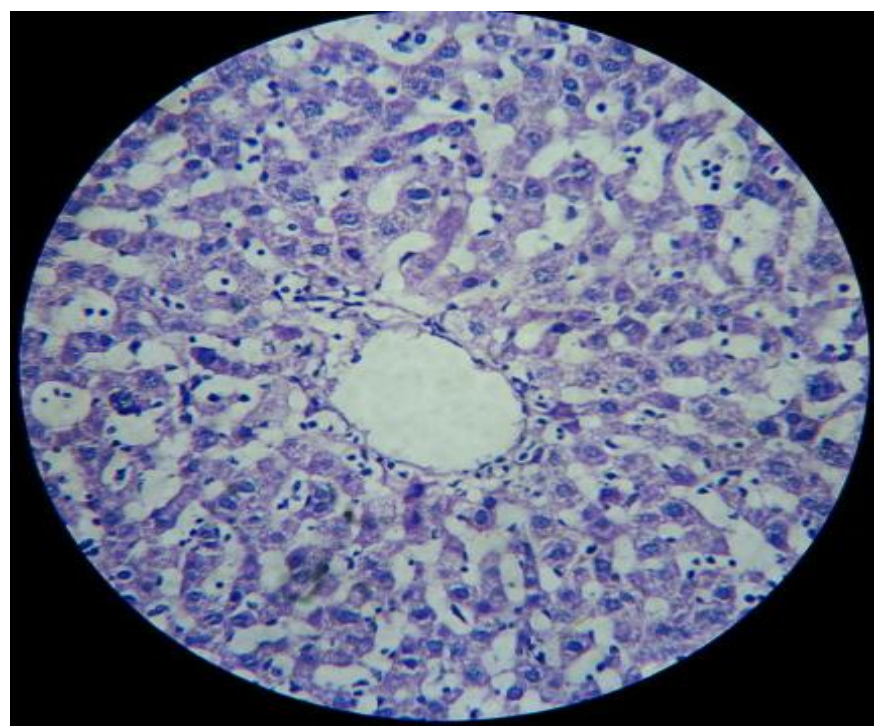

Fig. 2: Liver section from positive control groups reveals an acute hepatitis. ( H\&E, 40X).

3-Burn and S. aureus infected group: show all liver samples suffered from acute hepatitis represented by infiltration by inflammatory cells such as polymorphonuclear cells (Pmns) and large vacuoles of hepatocytes as shown in Fig 3a. On the other hand, lungs show picture of pneumonia, characterized by mixed inflammatory cells such as Pmns, plasma cells, histocytes and multiple patches of inflammatory areas (Fig 3b).

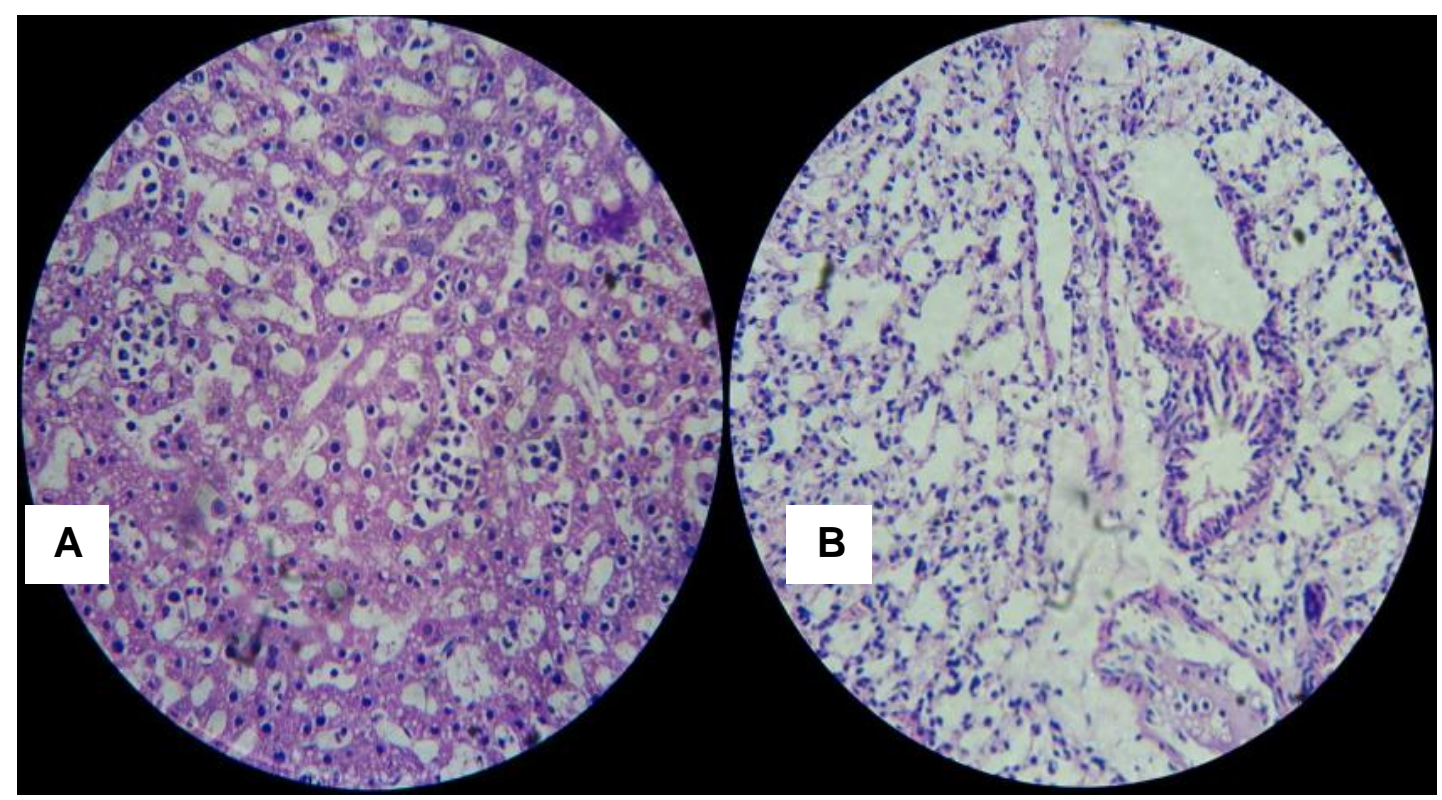

Fig. 3:a. Shows acute hepatitis in burn and $S$. aureus infected group,H\&E (40X), b. Shows picture of pneumonia in burn and $S$. aureus group, $H \& E(40 X)$. 
4-Burn and $P$. aeruginosa infected group suffered from different pathological changes. Livers show pictures of acute hepatitis, which represented by mixed inflammatory cells mainly Pmns, as explained in Fig. 4a. On the other hand, lungs show pneumonia, the picture refers to infiltrate of Pmns around bronchioles and present of lung abscesses (Fig.4b).

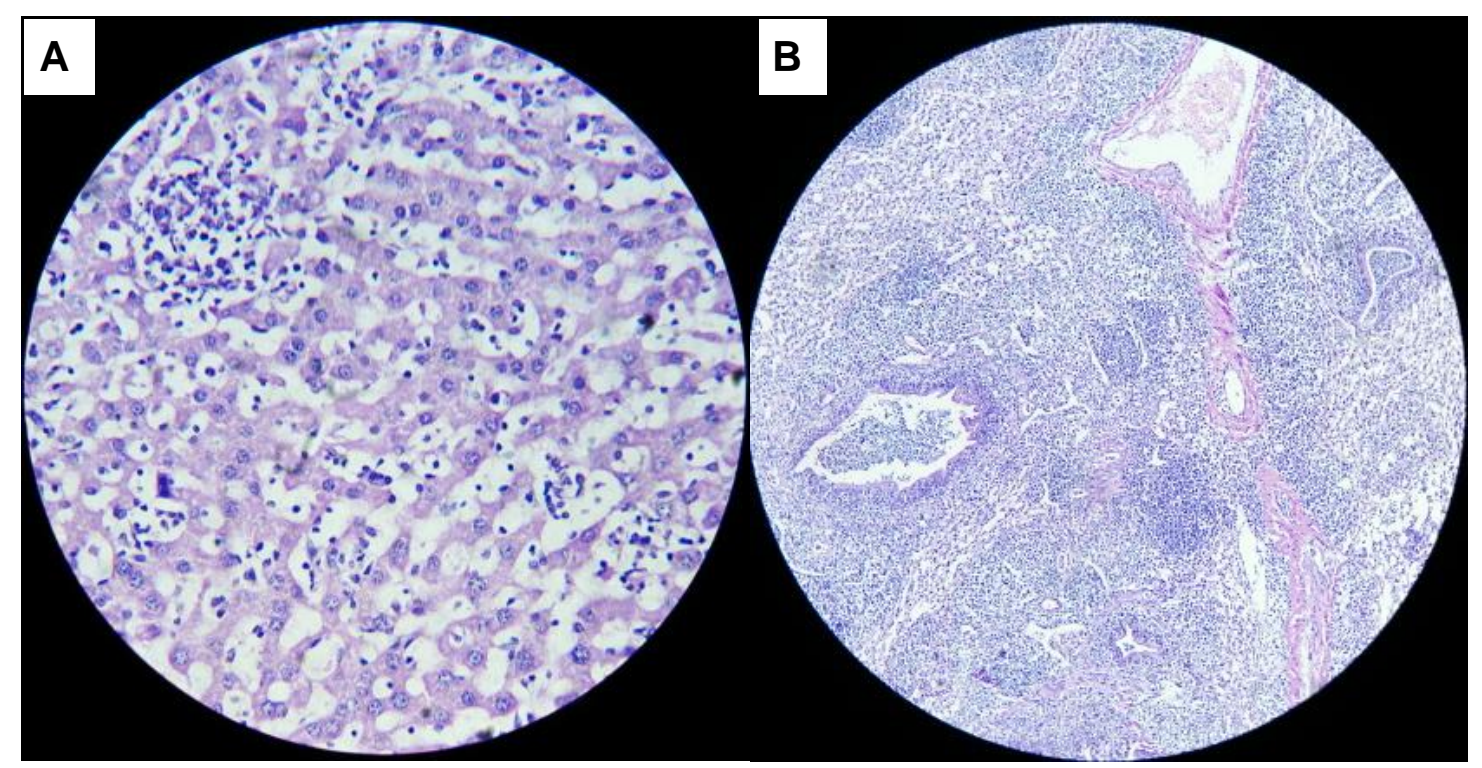

Fig. 4:a. Shows acute hepatitis of burn and $P$. aeruginosa infected group, H\&E (40X).b. Shows picture of pneumonia and lung abscess of burn and $P$. aeruginosa infected group, H\&E (40X).

\section{Discussion :}

Burns of large surface area may turn into a systemic problem, affecting a diverse range of organs and generating high levels of morbidity and mortality. There are a hypercatabolic state and immunosuppression resulting in an increased risk of infection and subsequently death. In the present study, burn wound infection was diagnosed by histopathological examination when microorganisms were observed to be invading viable tissue beneath the eschar, and the current results agree with these of Pruitt,1983. Histological examination of the burn biopsy specimen shows invasion of the infectious organism into adjacent viable tissues; so in present study burn infection organisms reisolated from internal organs such as liver and lung and produce multiple hitopathological changes, these results were similar to results obtained by AlMaliky, (16). In present study, liver and lung of the studied samples suffered from hepatitis and variety degree of pneumonia which were due to the complications of bacteremia and septicemia of burned model and these results were consistent with other studies obtained by Horton et al. (17). 


\section{Refrences:}

1. Brigham PA, McLoughlin E. Burn incidence and medical care use in the United States: estimates, trends, and data sources. J Burn Care Rehabil. 1996;17(2):95-107.

\section{2. http://www.ameriburn.org.}

3. McCaig LF, Burt CW. National Hospital Ambulatory Medical Care Survey: emergency department summary. Adv Data. 2004;18(340):134.

4. Organization WH. The Global Burden of Disease: Geneva; Available from www. who. int/ health info / global

burden_disease/GBD_report_2004 update full. pdf.

5. Ashburn MA. Burn pain: The management of procedure-related pain. J Burn Care Rehabil. 1995;16(3 Pt 2):365-371.

6. Summer GJ, Puntillo KA, Miaskowski C, Green PG, Levine JD. Burn injury pain: the continuing challenge. J Pain. 2007;8(7):533-548.

7. Hawkins A, Maclennan PA, McGwin Jr G, Cross JM, Rue LW, 3rd. The impact of combined trauma and burns on patient mortality. J Trauma. 2005;58(2):284-288.

8. Corry NH, Klick B, Fauerbach JA. Posttraumatic stress disorder and pain impact functioning and disability after major burn injury. J Burn Care Res. 2010;31(1):13-25.
9. Taal LA, Faber AW. Burn injuries, pain and distress: exploring the role of stress symptomatology. Burns. 1997;23(4):288-290.

10. Iurk LK, Oliveira AF, Gragnani A, Ferreira LM. Evidências no tratamento de queimaduras. Rev Bras Queimaduras. 2010;9(3):95- 99.

11. O'Sullivan ST, O'Connor TPF. Immunosuppression following thermal injury: the pathogenesis of immunodysfunction. Br J Plast Surg 1997; 50:615-23.

12. Mooney DP, Gamelli RL. Sepsis following thermal injury. Compr Ther 1989; 15:22-9.

13. Rosenthal N, Brown S. The mouse ascending: perspectives for humandisease models. Nat Cell Biol. 2007;9(9):993-999.

14- Ramos M, Gragnani A, Ferreira LM. Is there an ideal animal model to study hypertrophic scarring? J Burn Care Res. 2008;29(2):363-368

15- Pruitt BA Jr, Goodwin CW Jr. Current treatment of the extensively burned patient. Surg Annu 1983; 15:331-64.

16- Haydar, Kh., Shanan. Experimental study of bacterial burn infection in Rabbits. Ph.D. thesis, 2012

17- Horton, JW; Mass, DL; White, J. and Minei, JP.Reducing susceptibility to bacteremia after experimental burn injury: a role for selective decontamination of the digestive tract. J. Appl. Physiol 2007; 102: 2207-2216. 


\section{دراسة تاثير البكتريا الملوثة للحروق في نموذج الحرق التجريبي رحمن لتيبي جلاب

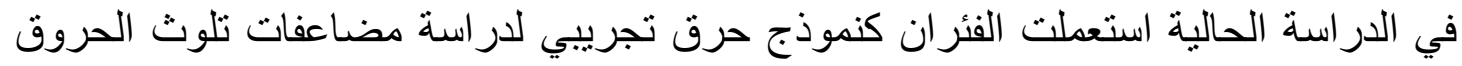

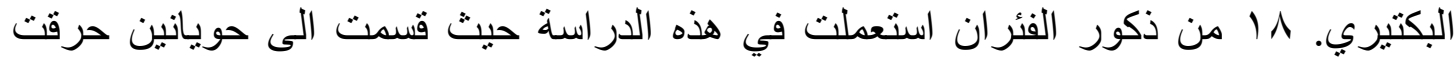

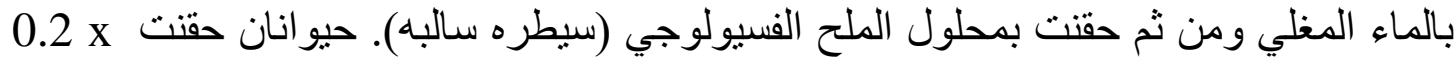

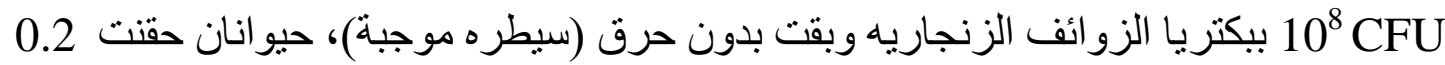
ب $10^{8}$ CFU

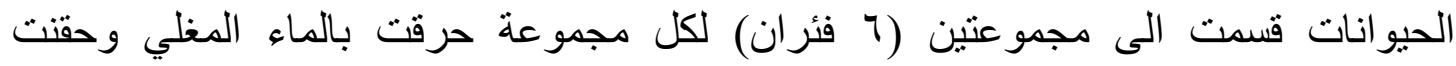

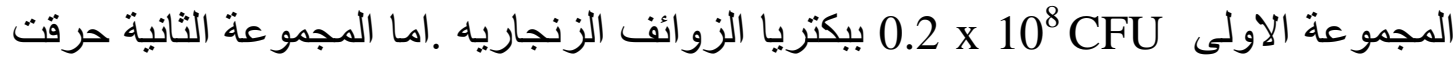

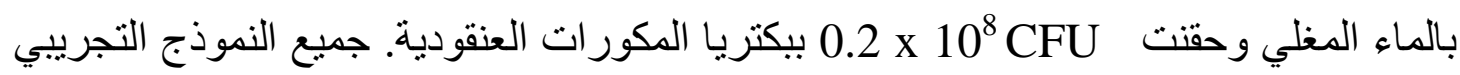

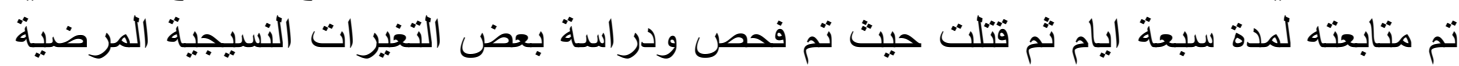

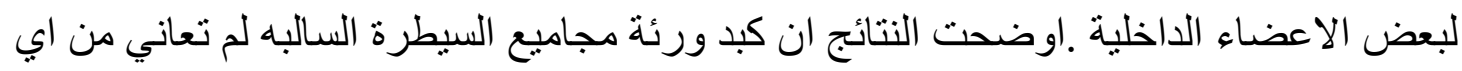

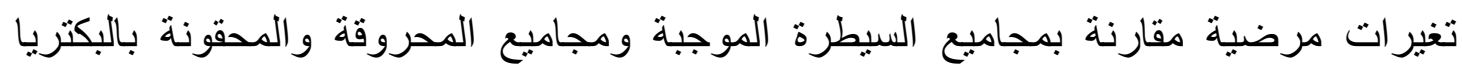

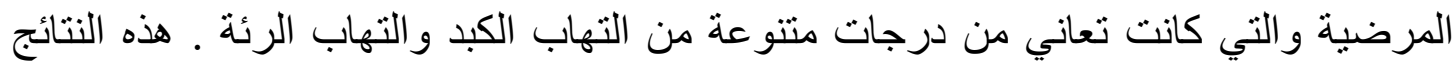
كانت نتيجة تجرثم و عفونية الدم للنموذج التجريبي. 